\title{
Model of sustainable land management (study at Bukit Sepuluh Ribu area of Bungursari Sub-District, Tasikmalaya City, West Java)
}

\author{
D. Ramdhani ${ }^{1}$, S. W. Utomo ${ }^{1,2^{*}}$, H. Thayib ${ }^{1}$, Y. Wardhana ${ }^{1}$ \\ 1Environmental Science Study Program, School of Environmental Sciences, University of Indonesia, \\ Jakarta, Indonesia \\ 2Department of Environmental Health, Faculty of Public Health, University of Indonesia, Jakarta, Indonesia
}

\begin{abstract}
Abstrak.
Penelitian ini berkaitan dengan meningkatnya tekanan pada sumber daya di bukit akibat konversi lahan yang menyebabkan degradasi lingkungan dan mengarah pada ketidakberlanjutan lingkungan. Bukit yang tersebar merata yang dikenal dengan nama Bukit Sepuluh Ribu adalah sumber kehidupan bagi masyarakat sekitarnya. Bukit yang dibentuk oleh letusan gunung berapi ini memiliki tutupan lahan yaitu dekat dengan vegetasi hutan. Lokasi penelitian berada di kawasan Bukit Sepuluh Ribu yang memiliki fungsi lingkungan secara ekologis, hidrologis, geologis dan estetika. Konsep pemberdayaan masyarakat melalui Agroekosistem dapat menjadi solusi, sehingga pemanfaatan bukit ini menguntungkan secara ekonomi dan berkelanjutan secara lingkungan. Terdapat penggunaan lahan seluas 682,9 Ha yang tidak sesuai dengan rencana tata ruang, yaitu digunakan sebagai daerah pemukiman padat $(264,67 \mathrm{Ha})$, pertanian lainnya $(359,21$ $\mathrm{Ha}$ ) dan daerah pertambangan (58,51 Ha). Melalui konsep pemberdayaan masyarakat yang tepat sesuai dengan aturan dan tipologi kawasan perbukitan diyakini dapat memberikan manfaat ekosistem dan menghasilkan produk bernilai ekonomi tanpa merusak alam. Konsep pemberdayaan melalui agroekosistem lahan kering dengan menggabungkan kegiatan pertanian berbasis hutan adalah salah satu solusi untuk masalah pengelolaan lahan.
\end{abstract}

\begin{abstract}
.
This study is associated with the increased pressure on hill resources due to land conversion that causes environmental degradation and leads to environmental unsustainability. The evenly spread hill known as Bukit Sepuluh Ribu, is a source of community life. The hill formed by the eruption of a volcano, has a land cover, namely close to forest vegetation. The study location is in Bukit Sepuluh Ribu area that has ecological, hydrological, geological and aesthetic environmental function. The concept of community empowerment through Agro-ecosystem can be a solution, thus the utilization of the hill is economically profitable and environmentally sustainable. There are land use unsuitability referring to the existing spatial plan $(682.9 \mathrm{Ha})$, namely high densely settlement area $(264.67 \mathrm{Ha})$, other agriculture $(359.21 \mathrm{Ha})$ and mining areas $(58.51 \mathrm{Ha})$, Through the concept of appropriate community empowerment in accordance with the rules and typology of hill areas can provide the potential benefits of ecosystems and produce products of economic value without damaging them. The concept of empowerment through dryland agroecosystem by combining forest-based agriculture activities is one of the solutions to the problem of land management.
\end{abstract}

Keywords: land use transfer, environmental degradation, Bukit Sepuluh Ribu resources

Kata kunci: alih guna lahan, degradasi lingkungan, sumber daya Bukit Sepuluh Ribu

\section{INTRODUCTION}

The increased population in Bukit Sepuluh Ribu area caused massive change in the function of the hill land into non hill which lead to environmental unsustainability due to the living necessities and the economy of the surrounding community. This cycle needs to be limited by the implementation of sustainable development strategies in order to restore the environmental degradation, livelihood and primarily reduce poverty. It is important to ensure local livelihoods of communities on environmental conservation and conservation

\footnotetext{
${ }^{*}$ Korespondensi Penulis

Email : suyudwarno@gmail.com
} 
programs to pursue a strategy that can outline issues directly at the household and community levels. The importance of land-use policies and land-use planning ensures that land use is sustainable and useful for people's livelihoods (Kombo and Ekisa 2015).

Community involvement in natural resource management, in principle is as a form of integration of public participation into the development system in order to strengthen the economic, institutional and social community (Mukhtar 2010). The concept of community empowerment through Agro-ecosystem can improve the quality of the environment, provide economic value by not degrading environmental functions and benefits (Pranadji 2015).

The definition of empowerment according to Sulistiyani (2004) derives from the word "power" which means strength and ability. It is a process of obtaining the power, strength and ability from the party with power to less or less powerful party. The goal of empowerment is to ensure livelihoods of local communities in environmental conservation and conservation programs to pursue strategies that can address problems directly at both household and community levels (Kombo and Ekisa 2015).

According to Pranadji (2015) the concept of dry land agro-ecosystem is one of the community empowerment strategies, by directing the environmental utilization economically without damaging it. A critical plantation greening program with perennials can fertilize dry land and produce high value economic products (environmental services for communities who manage local dryland).

Agro-ecosystem is a reciprocal agriculture between a group of people (community) and the physical environment of its environment in order to enable the survival of the group of people (the community). Agro-ecosystem derived from the word system, ecology and agro (Anonymous 2011). A system is a unity of interrelated and influencing components thus there is a harmonious process. Ecology is the science of the reciprocal relationship between an organism and its environment. Meanwhile ecosystem is a system consisting of biotic and abiotic components involved in a joint process (energy flow and nutrient cycle).

According to Odum (1993) ecosystem means an entire and whole order of unity between all elements of abiotic and biotic environment that interact. It is therefore possible that one or more of its components may indicate or as an indicator of other components of the same ecosystem.

Agricultural activities are always associated with agroecological factors, which include both biotic and abiotic components interacting with agroecosystem. Man-managed farming systems, cultivated crops planted will interact with the surrounding ecology. The ecological mechanism occurred is determined by the composition of agricultural crops and also determined by abiotic factors such as soil chemistry, climate and management or agricultural degradation. To 
maintain the interaction between these biotic and abiotic components, a sustainable agriculture system is needed, namely agriculture that maintains the environmental quality and conservation of natural resources (Warren et al. 2008).

\section{METHODOLOGY}

The study location is in Bukit Sepuluh Ribu Area, Bungursari Sub-District, Tasikmalaya City. This study uses quantitative approach. Nevertheless, the study method used is a combination of quantitative and qualitative methods (mix method). The quantitative method is used for data collection through satellite image digitization, questionnaires, laboratory identification and direct measurement, while the qualitative method uses interviews with community leaders, relevant offices and other stakeholders. Sampling is done by using slovin formula and the determination of respondent is using purposive sampling. From 9,477 head of families is obtained in total 383 respondents and 33 stakeholder respondents. The environmental samples are air quality and surface water. The types of data collected are primary and secondary data. Questionnaire items on the questionnaire are arranged by Likert scale.

\section{RESULT AND DISCUSSION}

Land use analysis, environmental, social and economic conditions analysis and stakeholder role analysis will be the basis for modelling that can be applied to Bukit Sepuluh Ribu Area.

\subsection{Analysis of land use suitability in Bukit Sepuluh Ribu Area}

The spatial use pattern of Tasikmalaya City area covers the protected and cultivation areas, set at Tasikmalaya City Spatial Plan of 2011-2031 on Local Regulation No. 4 Year 2012 about regional spatial plan for Tasikmalaya City in 2011-2031(Figure 1).

Comparison of land use based on the Tasikmalaya City Spatial Plan of 20112031 and the existing condition shown at Table 1. The results of the analysis indicate that there is deviation or unsuitability of land use to the area that exceeds the provision or planning in the spatial plan already defined, i.e 682.9 Ha for high densely settlement area $(264.67 \mathrm{Ha})$, other agricultures $(359.21 \mathrm{Ha})$ and mining area (58.51 $\mathrm{Ha})$. 


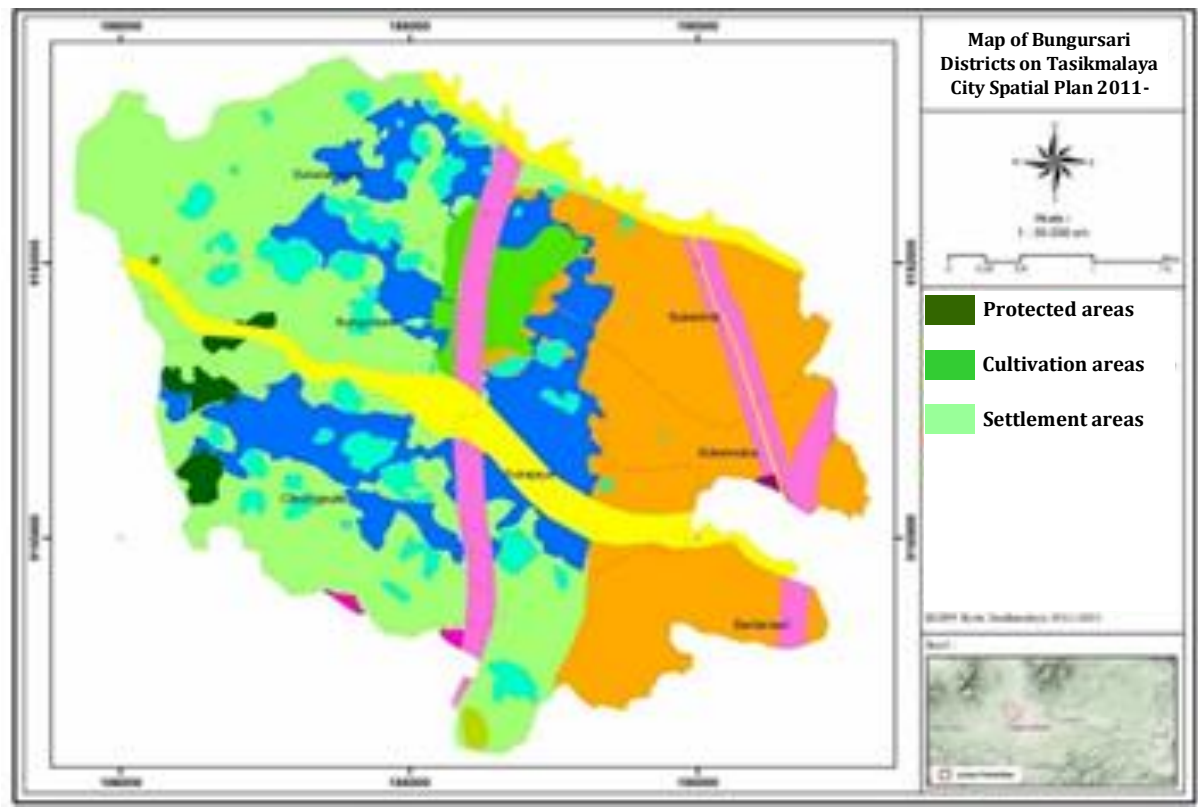

Figure 1. Land use map of Bukit Sepuluh Ribu area.

Table 1. Comparison of land use based on the spatial plan and the existing condition.

\begin{tabular}{|c|c|c|c|}
\hline Land use & Spatial Plan (Ha) & Existing ( $\mathrm{Ha})$ & $\Delta$ Delta $(\mathrm{Ha})$ \\
\hline Water absorption & 23.47 & 22.76 & 0.71 \\
\hline Situ Borderline & 4.38 & 4.38 & 0.00 \\
\hline Low density & 580.90 & 283.07 & 297.83 \\
\hline Medium density & 407.86 & 252.92 & 154.93 \\
\hline High density & 0.06 & 264.73 & -264.67 \\
\hline Other agricultures & 50.31 & 409.52 & -359.21 \\
\hline Industrial warehouse & 3.46 & 3.46 & 0.00 \\
\hline Minapolitan & 258.70 & 174.31 & 84.39 \\
\hline Trade \& services & 128.83 & 65.67 & 63.16 \\
\hline Offices & 1.35 & 1.35 & 0.00 \\
\hline Mining & 118.75 & 187.25 & -58.51 \\
\hline High-tension transmission lines & 4.10 & 4.10 & 0.00 \\
\hline General Cemetery & 0.50 & 0.50 & 0.00 \\
\hline Lava flow & 135.45 & 28.37 & 107.07 \\
\hline Total & $1,718.59$ & $1,718.59$ & \\
\hline
\end{tabular}

\subsection{Land use based on time series of 2002, 2014 and 2016}

Based on the digitization of land cover satellite image, land use change class of Bukit Sepuluh Ribu Area in Bungursari Sub-District in 2016 most in the form of agriculture and plantation (409.52 Ha), settlement (802.06 Ha) and mining (187.25 Ha). Changes in the land use of Bukit Sepuluh Ribu area are related to the population growth rate, economic activity and regional development. Table $\mathbf{2}$ show the land use of Bukit Sepuluh Ribu area in time series. 
Table 2. Changes in the land use of Bukit Sepuluh Ribu area in 2002, 2014, 2016.

\begin{tabular}{ccccccc}
\hline Year & $\begin{array}{c}\text { Trade and } \\
\text { Service } \\
\text { (Ha) }\end{array}$ & $\begin{array}{c}\text { Minapolitan } \\
\text { (Ha) }\end{array}$ & $\begin{array}{c}\text { Settlement } \\
\text { (Ha) }\end{array}$ & $\begin{array}{c}\text { Mining } \\
\text { (Ha) }\end{array}$ & $\begin{array}{c}\text { Agriculture \& } \\
\text { Plantation } \\
\text { (Ha) }\end{array}$ & $\begin{array}{c}\text { Open } \\
\text { Green } \\
\text { Space (Ha) }\end{array}$ \\
\hline 2002 & 19.40 & 36.86 & 243.97 & 6.49 & $1,184.90$ & 227 \\
2014 & 30.87 & 53.08 & 294.58 & 72.70 & $1,126.40$ & 141 \\
2016 & 69.13 & 57.6 & 802.06 & 187.25 & 409.52 & 102.10 \\
\hline
\end{tabular}

Based on Table 2 the land use increase occurs in the land use types of trade and services, minapolitan, settlement and mining. In contrast, agricultural land and plantations and open green space have decreased, where in 2014-2016 the agricultural and plantation areas decreased by $42.34 \%$. The changes in the land use of Bukit Sepuluh Ribu area in time series can be seen in Figure 2.

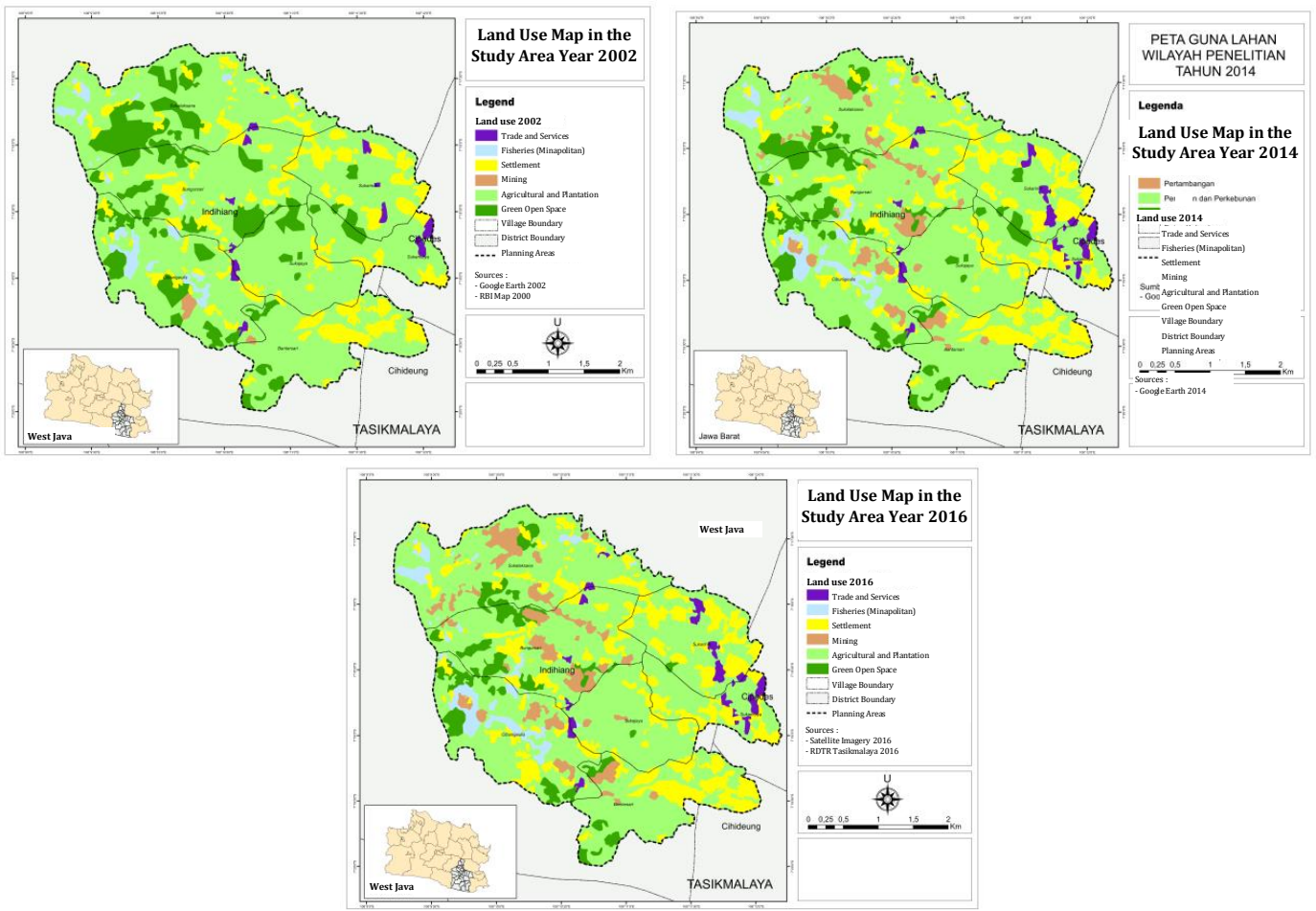

Figure 2. Time-series of land use map in 2000, 2014 and 2016.

\subsection{Environmental, social and economic condition of the people in hill area}

The turbidity of water and air monitoring are necessary, especially the water is used directly by the community for agricultural, plantations and fisheries activities. The test results show that the existing water quality based on the Government Regulation No. 82 Year 2001 is still below the quality standard 
which means that it can still be used for agricultural and freshwater fishery cultivation activities. As for the air quality is at the observation point of a distance of \pm 250 meters from the community settlement, with reference to the Government Regulation No. 41 Year 1999, i.e $0.37 \mathrm{mg} / \mathrm{m}^{3}$ already above the standard quality. The following sample locations (water and air) are shown in Figure 3.

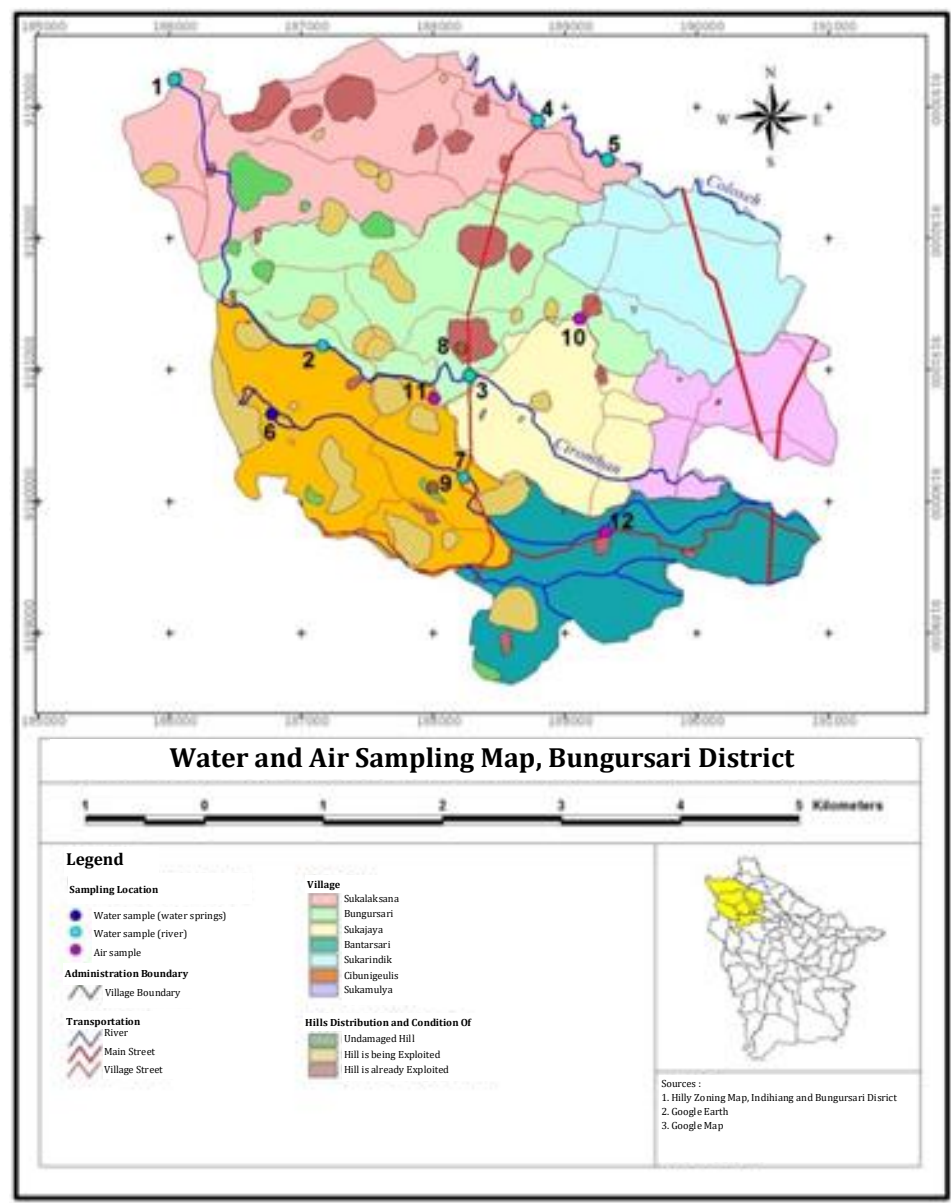

Figure 3. Location of water and air sampling map.

The economic impacts of the efforts of development activities, especially the land function transfer has not been able to provide the economic equity of the people. The improved communities are migrants and the people who suffer from a decrease in income levels are local farmer groups. The opening of job opportunities are services of vehicles, leased house and food stalls. The decrease in agricultural land affects the current pattern of work, starting to shift to nonagricultural sectors. The large number of employments arising from nonagricultural activities in this case is the mining activity of 0.65 . 
Impact on the social aspects is the emergence of disputes within the community consisting of vertical and horizontal constellations. Horizontal conflict occurs between individuals who are still siblings or still have family relationships. This conflict is a conflict of ownership of land and hill which is claimed as the right of each party or group of disputes. The land has no proof of ownership, thus there is a difference of principle in one of the parties in conflict. Further vertical conflicts between communities and mining entrepreneurs occur, because the study location is in massive hill mining activities. The people are disturbed as a result of heavy equipment activities that sometimes operate until night. The disturbance in water sources such as drought in a dry season becomes the most common problem complained by the community.

\subsection{Stakeholder role analysis}

The role of community measured through the level of public participation with the instrument of participation from Arnstein with eight ladders of public participation is at the level of manipulation which means there is no communication or dialogue between the government and the community. The limited number of people who know about information on activities related to the hill land indicates that communication between the government and the community has not gone well.

The role of government in this case is seen from the implementation of duty and authority of the Office of Environment, namely from a special policy device related to the management or protection of Bukit Sepuluh Ribu Area is still not available and has not been able to make efforts to realize, increase and develop partnerships with the community in supporting the sustainability of the hill area.

\subsection{Sustainable land management model}

Hill management efforts are currently already conducted by the community although minimal but still can be improved to reach the optimum level. The concept of a combination of agriculture and hill land can be developed through agro-ecosystem. The concept of agro-ecosystem through planting of wood species and fruit plants initiated by community groups has been done by some people. Benefits generated will be enjoyed by the surrounding community such as the sale of wood later for social and religious activities and village cash. In addition to wood, the fruits will also be enjoyed by the community.

In accordance with the existing potential natural resources and the result of incentive discussion with stakeholders, Bukit Sepuluh Ribu Area can be developed for the concept of community empowerment through a forest-based dry land agro-ecosystem model that combines the components or activities of agriculture (species of wood and fruit trees) and hill ecosystem in the hill and former hill land. 


\section{CONCLUSIONS AND SUGGESTIONS}

The high level of land transfer function is closely related to the factors of increasing population, the economic needs of infrastructure and community development. The development or management of the potential resources has tended to pursue improvements in the productivity and quality of agricultural products, but has little regard for stability and sustainability. The involvement of communities in natural resource management, in principle is as a form of integration of public participation into the development system in order to strengthen the economic, institutional and social community.

The conclusions of this research are there is the unsuitability of land use in the Bukit Sepuluh Ribu Area according to the designated spatial plan, a decline on environmental, economic and social functions caused by development activities, especially the land transfer, and also the lack of role and participation of stakeholders in the existence of the hill sustainability. The dryland agroecosystem model can be a solution as a suitable community empowerment strategy based on the regional typology and the community characteristic in the hill area.

\section{REFERENCES}

Anonymous. 2011. Pengertian agroekosistem [internet]. Tersedia di: http://www.artikata.com/arti-318031-agroekosistem.html.

Government Regulation No. 41 Year 1999 on air pollution control.

Government Regulation No. 82 of 2001 on water quality management and water pollution control.

Kombo NP and Ekisa GT. 2015. The Impact of land use change on livelihood of the massai community in Kajiado Country, Kenya. Ethiopian Journal of Environmental Studies and Management 8(4):433-441.

Local Regulation No. 4 Year 2012 on regional spatial plan for Tasikmalaya City in 2011-2031.

Mukhtar. 2010. Pengelolaan program hutan kemasyarakatan berbasis kearifan lokal: studi kasus di kawasan hutan lindung Sesaot Lombok Barat. Jurnal Wacana 13(1):132-151.

Odum EP. 1993. Dasar-dasar ekologi: volume ke 3. Terjemahan dari: Fundamentals of Ecology. Universitas Gadjah Mada Press. Yogyakarta.

Pranadji T. 2015. Model pemberdayaan masyarakat pedesaan untuk pengelolaan agroekosistem lahan kering [Tesis]. Institut Pertanian Bogor. Bogor.

Sulistiyani AT. 2004. Kemitraan dan model-model pemberdayaan. Gaya Media. Yogyakarta.

Warren J, Lawson C and Ken B. 2008. The agri-environment. Cambridge University Press. New York. 